\title{
Deteksi Non-RTH(Ruang Terbuka Hijau) Kota Malang Berbasis Citra Google Earth Dengan Menggunakan Naïve Bayes Classifier
}

\author{
Irwan Budi Santoso \\ Jurusan Teknik Informatika, Sains dan Teknologi \\ Universitas Islam Negeri (UIN) Maulana Malik Ibrahim Malang \\ irwan.budi331177@gmail.com
}

\begin{abstract}
Banjir, polusi udara dan naiknya temperatur udara di perkotaan, dewasa ini semakin marak persoalan tersebut tidak lain bersumber dari aktifitas manusia yang tidak terkendali sehingga mengakibatkan kerusakan. Salah satu upaya yang bisa dilakukan untuk membantu menyelesaikan persoalan tersebut adalah adanya fasilitas yang dapat memantau kondisi lingkungan secara riil berupa non-Ruang Terbuka Hijau (non-RTH), melalui komputer. Penyediaan fasilitas tersebut sangatlah mungkin dilakukan dengan memanfaatkan foto satelit seperti yang disediakan oleh Google Earth. Studi kasus dalam penelitian ini adalah kota Malang, dengan metode yang digunakan untuk mendeteksi objek non-RTH dipermukaan bumi kota Malang berdasarkan image atau citra satelit adalah Nä̈ve Bayes Classifier (NBC).Hasil uji coba dengan menggunakan sampel pengujian, menunjukkan tingkat akurasi metode tersebut dalam mendeteksi objek non-RTH kota Malang adalah $81 \%$.
\end{abstract}

\section{Kata Kunci: Image , cropping, Nä̈ve Bayes Classifier, Training, Akurasi}

\section{I.PENDAHULUAN}

Persoalan banjir, polusi udara dan naiknya temperatur udara di perkotaan, dewasa ini semakin marak serta menjadi berita tahunan. Tidak dipungkiri persoalan tersebut tidak lain bersumber dari aktifitas manusia yang tidak terkendali sehingga mengakibatkan kerusakan. Salah satu upaya yang bisa dilakukan untuk membantu menyelesaikan persoalan tersebut adalah adanya fasilitas yang dapat memantau kondisi lingkungan secara riil baik berupa Ruang Terbuka Hijau (RTH) ataupun non-RTH. Sebagai misal Kota Malang sebagai kota pendidikan dan kota wisata, saat ini sedang menghadapi berbagai persoalan, diantaranya adalah semakin menyempitnya Ruang Terbuka Hijau (RTH) dan meluasnya non-RTH, yang hingga sekarang tercatat luas RTH-nya kurang dari 10\% (Halomalang, 2012) (Tempo, 2013) (Republika, 2015). Padahal menurut UndangUndang No. 26/2007 kebutuhan RTH adalah minimal $30 \%$ dari total luas wilayah kota (Depdagri,

2007), sehingga luas RTH yang kurang dari $10 \%$ akan sangat mempengaruhi dalam membentuk lingkungan kota yang nyaman dan sehat (Roswidyatmoko, 2013). Salah satu faktor yang menghalangi perluasan RTH adalah meningkatnya jumlah penduduk Kota Malang, dan hingga tahun 2013 saja sudah tercatat sebesar 840.803 jiwa (BPS Kota Malang, 2015). Hal tersebut meyebabkan kepadatan penduduk semakin besar dan berdampak semakin luasnya pemukiman (non-RTH) sehingga akan sulit memperluas RTH. Faktor lain yang juga mempersempit RTH adalah adanya alih fungsi hutan kota menjadi mall (Halomalang, 2012), hotel, perkantoran dan lain-lain.
Dengan semakin menurunnya kuantitas ataupun kualitas RTH di Kota Malang dan bertambahnya kuantitas non-RTH berakibat menurunnya kualitas lingkungan perkotaan misalnya sering terjadi banjir (Antara,2010) (Kompas,2010) Tempo,2008,2009,2010), temperature semakin tinggi, polusi udara atau bahkan menurunkan tingkat produktivitas masyarakat akibat depresi (stress) karena keterbatasan ruang publik yang nyaman untuk berinteraksi sosial. Tidak dipungkiri persoalan tersebut tidak lain berasal dari aktifitas manusia yang mengakibatkan kerusakan (ketidakseimbangan) pada lingkungan hidup. RTH merupakan salah satu komponen ruang yang tingkat ketersediaannya harus selalu diperhitungkan dalam proses perencanaan kota, dan permasalahan utama keberadaan RTH adalah semakin berkurangnya RTH karena keterbatasan lahan dan ketidakkonsistenan dalam menerapkan tata ruang (Roswidyatmoko, 2013) yang diberuntukan untuk non-RTH. Salah satu upaya yang bisa dilakukan untuk membantu menyelesaikan persoalan tersebut adalah adanya teknologi yang dapat melakukan deteksi nonRTH secara cepat, mudah dan real time, sehingga mempermudah pemerintah dalam pemantauan dan perencanaan Kota Malang. Teknologi tersebut sangatlah mungkin dilakukan dengan memanfaatkan foto satelit seperti yang disediakan oleh Google Earth. Namun demikian informasi yang disediakan oleh industri tesebut hanya menampilkan foto satelit tanpa bisa melakukan deteksi non-RTH. Oleh karena itu diperlukan pengembangan teknologi lebih lanjut untuk deteksi non-RTH Kota Malang berdasarkan foto satelit. Berdasarkan hal tersebut, peneliti ingin melakukan penelitian membangun aplikasi deteksi non-RTH Kota Malang berdasarkan citra Google Earth dengan metode Nä̈ve Bayes 
Classifier (NBC) serta membangun beberapa struktur model pengenalan terbaik dalam mendeteksi non-RTH dengan menggunakan metode Nä̈ve Bayes Classifier (NBC).

\section{NAÏVE BAYES CLASSIFIER} (NBC)

Nä̈ve Bayes Classifier (NBC) adalah metode klasifikasi berbasis probabilitas dengan mengasumsikan diantara atribut atau fitur objek bersifat independen (Pablo, 2014). Naïve Bayes saat ini masih menjadi topik yang hangat, khususnya terkait dengan perbaikan metode tersebut untuk meningkatkan peformansi dalam klasifikasi. Dalam banyak aplikasi seringkali, diasumsikan fungsi peluang (probability density function) setiap atribut atau fiturnya berdistribusi Normal (Gaussian) maka (Andrew, 2011) sehingga asumsi tersebut sangat berpengaruh dalam pembentukan NBC. Bila diketahui fitur objek, $X=\left\{x_{1}, \ldots, x_{d}\right\}$ dan setiap fitur berdistribusi Normal (Gaussian) maka peluang fitur atau atribut dengan syarat diketahui kelas ke-j $\left(C_{j}\right)$ adalah

$$
P\left(X \mid C_{j}\right)=\prod_{k=1}^{d} P\left(X_{k} \mid C_{j}\right)=\prod_{k=1}^{d} N\left(x_{k} ; \hat{\mu}_{j k}, \hat{\sigma}_{j k}\right)
$$

dengan $\hat{\mu}_{j k}$ dan $\hat{\sigma}_{j k}$ adalah hasil estimasi parameter distribusi (Normal) $\mu$ dan $\sigma$ untuk fitur ke-k dan kelas k-j. Dengan mengunakan kaidah peluang bersyarat didapatkan persamaan sebagai berikut

$P\left(C_{j}, X\right)=P\left(C_{j}\right) P\left(X \mid C_{j}\right)=P\left(C_{j}\right) \prod_{k=1}^{d} N\left(x_{k} ; \hat{\mu}_{j k}, \hat{\sigma}_{j k}\right)$

Berdasarkan persamaan 2.2, maka untuk menentukan hasil klasifikasi berdasarkan atribut atau fitur objek yang diinputkan, berdasarkan nilai peluang terbesar dari $P\left(C_{j} \mid X\right)$. $\hat{c}=\underset{c_{j}}{\arg \max } P\left(C_{j}\right) \prod_{k=1}^{d} N\left(x_{k} ; \hat{\mu}_{j k}, \hat{\sigma}_{j k}\right)$

Dengan $\hat{c}$ adalah hasil klasifikasi atau deteksi.

\section{METODE PENELITIAN}

Tahapan-tahapan secara umum pada penelitian ini meliputi 4 proses yaitu perancangan dan pengumpulan data, desain sistem, implementasi sistem (coding), uji coba sistem yang dibangun. Adapun tahapan-tahapan penelitian bisa dilihat Gambar 3.1 (irwan,2014).
A. Perancangan dan Pengumpulan Data

Data yang akan digunkan dalam penelitian ini adalah data image (citra) yang diambil dari Google Earth khusus untuk kawasan Kota Malang tahun 2015 dengan ketinggihan sekitar $5000 \mathrm{ft}$. Data yang diperoleh dari Google Earth tersebut, akan digunakan sebagai data training untuk membangun struktur model pengenalan dengan menggunakan metode Nä̈ve Bayes Classifier (NBC) beserta parameter modelnya, dan digunakan sebagai data uji coba (testing) untuk menguji metode dan aplikasi yang telah dibangun. Data image objek nyata yang diambil melalui cropping citra kawasan Kota Malang adalah rumah, gedung/kantor, lapangan, sawah, jalan.

\section{B. Desain Sistem}

Desain Sist Desain sistem dalam penelitian ini meliputi 2 bagian utama yaitu deteksi non-RTH (training dan testing ) seperti telihat pada Gambar 4

Pada proses training, langkah pertama adalah cropping image objek dari citra sehingga terkumpul sampel training untuk setiap objek kelas. Langkah berikutnya adalah melakukan preproses terhadap image objek yang telah diambil melalui cropping berdasarkan hasil pada perancangan dan pengumpulan data, kemudian dilakukan ekstraksi fitur untuk mendapat ciri objek yang mewakili. Setelah dilakukan ekstraksi fitur dibangun struktur model pengenalan dengan NBC dan hasilnya disimpan.

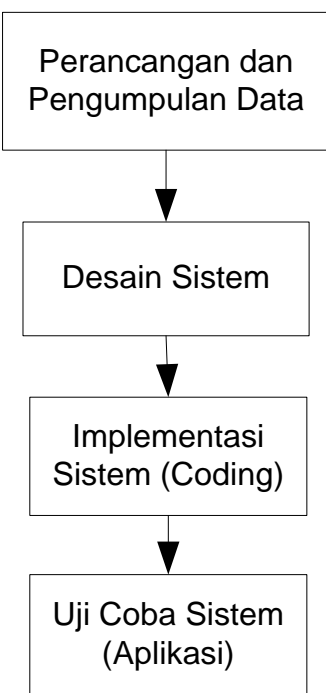

Gambar 1. Tahapan-tahapan umum penelitian 


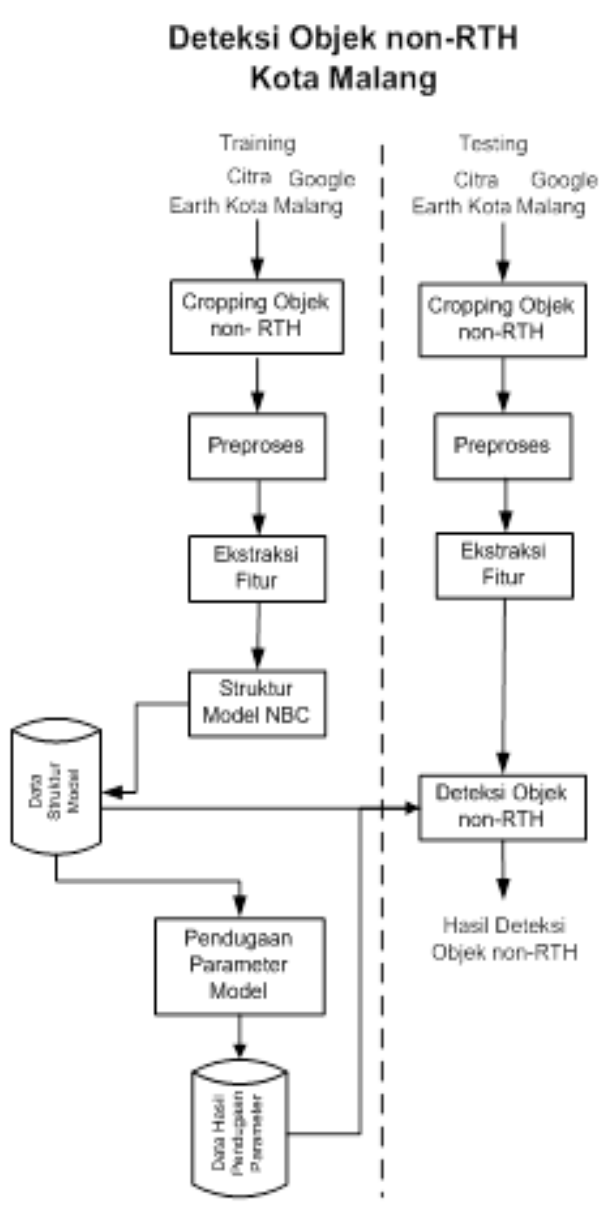

Gambar 2. Desain sistem penelitian deteksi nonRTH Kota Malang

Berdasarkan struktur model yang telah dibangun selanjutnya dilakukan estimasi parameter modelnya dan hasilnya juga disimpan. Sedang pada proses testing, langkah pertama adalah cropping image objek yang akan dideteksi dari citra, selanjutnya melakukan preproses pada data image objek tersebut, kemudian ekstraksi fitur dan dengan menggunakan beberapa struktur model NBC (multi model NBC) yang telah dibangun (lihat Gambar 3) dan parameter hasil estimasi, selanjutnya dapat dilakukan proses deteksi objek non-RTH berdasarkan image citra .

\section{HASIL DAN PEMBAHASAN}

A. Implementasi Disain Sistem Aplikasi

Implementasi desain sistem deteksi non-RTH berdasarkan citra, dibagi menjadi beberapa bagian yaitu akuisisi data (memuat cropping obyek), preproses, training data dengan NBC (memuat ekstraksi fitur objek non-RTH, dan estmasi parameter model NBC), dan deteksi objek non-RTH.

Proses akuisisi data, digunakan untuk membuka file image (citra) yang akan digunakan sebagai data training ataupun testing. Pada bagian ini ada proses cropping image objek non-RTH yang dilengkapi dengan fasilitas untuk menyimpan file objek non-RTH seperti pada Gambar 3 Sedangkan Preproses digunakan untuk merubah image objek hasil cropping menjadi image grayscale. Menu preproses dilengkapi dengan fasilitas menyimpan file pada direktori tertentu. Proses merubah image RGB hasil cropping menjadi image grayscale dilakukan secara serentak dengan melibatkan sejumlah sampel image dan menyimpan secara serentak dalam direktori tertentu

Pada proses Training data, training selain digunakan untuk membangun struktur model NBC dan estimasi parameternya juga memuat ekstraksi fitur image objek. Input dari aplikasi Training adalah sejumlah sampel data image objek deteksi image Objek non-RTH

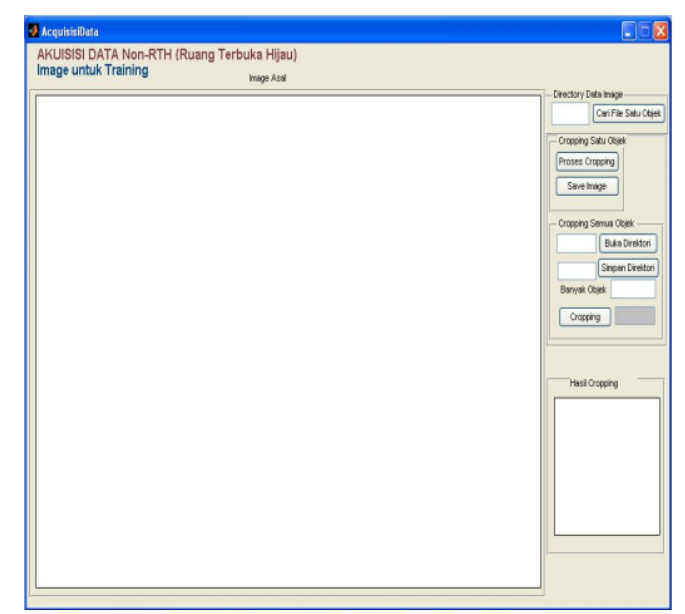

Gambar 3 Tampilan aplikasi akuisisi data image objek untuk training dan testing

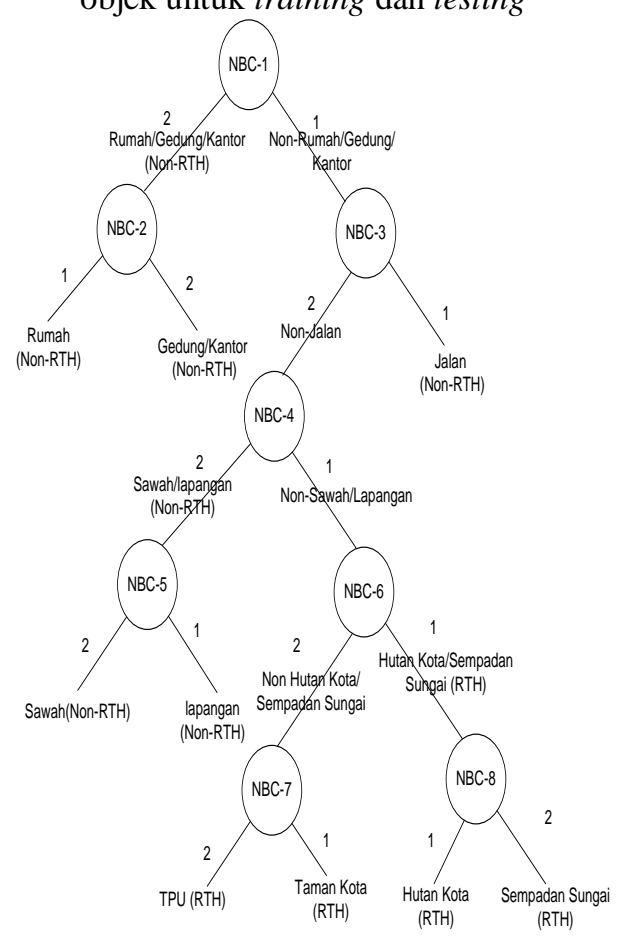

Gambar 4 Struktur multi model NBC untuk Deteksi Image Objek non-RTH 
juga melibat data image objek RTH. Sedangkan input selain data image adalah ukuran maksimum dimensi image objek (biasanya lebih kecil dari image semula). Metode yang digunakan merubah dimensi image objek dengan menggunakan interpolasi nearest neighbor. Hasil dari optimaliasi training adalah dapat diektahui ukuran atau dimensi image objek yang paling baik sedemikian hingga terbaik akurasinya.

Sedangkan proses deteksi objek non-RTH adalah suatu proses untuk mendeteksi image objek non-RTH yang diambil dari citra dengan mengklasifikan image objek ke dalam kelas yang sesuai dengan kelas riil. Proses ini dilakukan dengan input data image objek nonRTH yang dicropping dari citra . Aplikasi deteksi objek non-RTH selengkapnya dapat dilihat pada Gambar 5.

\section{B. Uji Coba Sistem}

Uji coba sistem secara garis besar meliputi dua bagian yaitu pertama uji coba aplikasi dalam membangun model deteksi objek non-RTH dengan melibatkan beberapa struktur model NBC (multi model NBC) meliputi NBC-1, NBC-2, NBC-3, NBC-4, NBC-5, NBC-6, NBC7 dan NBC-8. Struktur model deteksi objek nonRTH yang melibatkan beberapa model NBC tersebut, mengacu pada struktur deteksi dalam bentuk tree seperti Gambar 4. Uji coba kedua adalah uji coba aplikasi dalam mendeteksi image objek non-RTH yang diambil dari citra Google Earth Kota Malang.

Dari hasil training membangun struktur model NBC tersebut, selanjutnya dihasilkan struktur multi model TAN dalam bentuk tree, dengan melibatkan NBC-1, NBC-2, NBC-3, NBC-4, NBC-5, NBC-6, NBC-7 dan NBC-8, seperti pada Gambar 6.

Hasil uji coba dengan menggunakan 100 sampel image objek non-RTH yang terdiri dari 20 sampel image objek RTH rumah tinggal, 20 image objek gedung/kantor, 20 image objek lapangan, 20 image objek sawah dan 20 image objek jalan, secara umum menunjukkan bahwa sistem dapat mendeteksi dengan akurasi $81 \%$. Secara rinci hasil deteksi tersebut tunjukkan dengan matrik confusion seperti pada Gambar 7

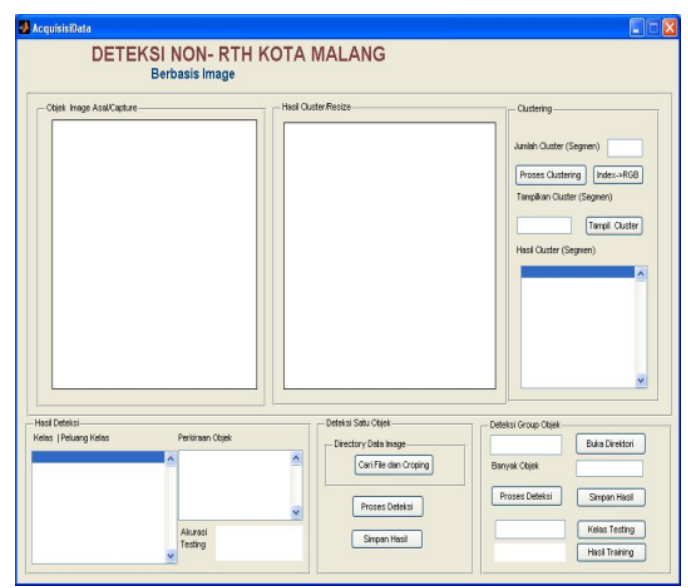

Gambar5 Tampilan aplikasi

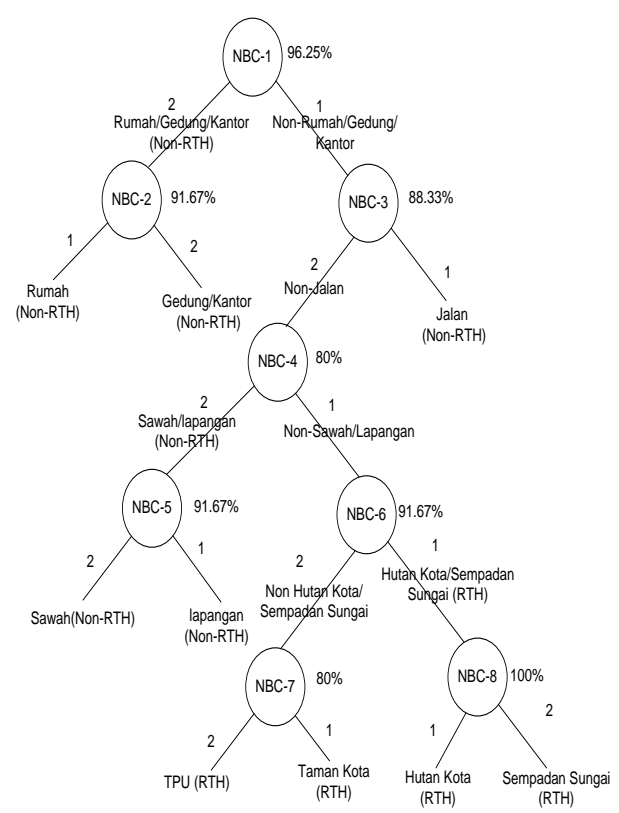

Gambar 6 Struktur multi Model NBC untuk mendeteksi non-RTH Kota Malang

\begin{tabular}{c|ccccccccc} 
& $\mathbf{1}$ & $\mathbf{2}$ & $\mathbf{3}$ & $\mathbf{4}$ & $\mathbf{5}$ & $\mathbf{6}$ & $\mathbf{7}$ & $\mathbf{8}$ & $\mathbf{9}$ \\
\hline $\mathbf{1}$ & 17 & & & & & 1 & 2 & & \\
$\mathbf{2}$ & 1 & 17 & & & 1 & 1 & & & \\
$\mathbf{3}$ & 2 & & 18 & & & & & & \\
$\mathbf{4}$ & & & 6 & 11 & 3 & & & & \\
$\mathbf{5}$ & & & & 1 & 18 & & & 1 &
\end{tabular}

*) 1=Rumah(non-RTH), 2=Gedung/Kantor(non-RTH), 3=Jalan(non-RTH), 4=Lapangan(non-RTH), 5=Sawah(nonRTH), 6=Taman Kota(RTH), 7=TPU(RTH), 8=Hutan Kota (RTH), 9=Sempadan Sungai (RTH)

Gambar 7 Matrik confusion deteksi obyek nonRTH Kota Malang 


\section{V.}

KESIMPULAN

Langkah-Langkah dalam membangun aplikasi deteksi non-RTH Kota Malang berdasarkan image Google Earth antara lain, pertama membangun apliaksi akusisi data image objek non-RTH, kedua membangun aplikasi preproses untuk merubah image objek non-RTH menjadi grayscale, ketiga membangun aplikasi training data untuk mendapatkan beberapa struktur model NBC (multi model NBC) deteksi image objek non-RTH Kota Malang beserta estimasi parameternya, dan terakhir membangun aplikasi deteksi image objek non-RTH berdasarkan beberapa struktur model yang telah dibangun dan parameter yang telah diestimasi. Hasil uji coba dengan menggunakan 100 sampel image objek non-RTH yang terdiri dari 20 sampel image objek RTH rumah tinggal, 20 image objek gedung/kantor, 20 image objek lapangan, 20 image objek sawah dan 20 image objek jalan, secara umum menunjukkan bahwa sistem dapat mendeteksi dengan akurasi $81 \%$.

\section{REFERENSI}

[1] Antara. (2010). RTH Berkurang, Malang Jadi Kota Banjir. Surat Kabar Antara, 8 November 2010.

[2] Andrew.R. Webb and K.D. Cospey.(2011). Statistical Pattern Recognition. Third Edition. John Wiley \& Sons, Ltd.

[3] BPS Kota Malang. (2015). Jumlah Penduduk Kota Malang menurut Jenis Kelamin Tahun 2005-2013 [Online]. Dapat diakses di malangkota.bps.go.id, 23 Februari 2015.

[4] Departemen Pekerjaan Umum. (2008). Peraturan Menteri Pekerjaan Umum No. 5/PRT/M/2008 Tentang Pedoman Penyediaan dan Pemanfaatan Ruang Terbuka Hijau di Kawasan Perkotaan.

[5] [Depdagri] Departemen Dalam Negeri. (2007). Undang-undang No. 26 Tahun 2007 tentang penataan ruang. Jakarta: Depdagri.

[6] Faikoh. (2008). Deteksi Perubahan Ruang Terbuka Hijau. Sekripsi, Departemen Arsitektur Lanskap Fakultas PertanianIPB.

[7] Halomalang. (2012). Ruang Terbuka Hijau Di Malang Semakin Menyusut [Online]. Dapat diakses di halomalang.com. 23 Februari 2015.

[8] Irwan, B.S. (2012). Model Pengenalan Terbaik Dengan Tree-Augmented Newtork (TAN) dan Estimator Maximum Likelihood (ML) Berdasarkan Fitur Objek. Jurnal MATICS. No. 5, Vol. 4, Halaman 197-203.

[9] Irwan, B.S. (2012). Model Pengenalan Karakter Tulisan Tangan Terbaik Dengan
Dengan Tree-Augmented Network (TAN) dan Estimator Maximum Likelihood. Jurnal MATICS, No. 1, Vol. 5, Halaman 21-27.

[10] Irwan, B.S.(2012). Peningkatan Akurasi Sistem Pengenalan Karakter Tulisan Tangan dengan Multi Model Tree-Augmented Network (TAN). Prosiding Seminar Nasional Green Technology 3.

[11] Irwan, B.S.(2013). Aplikasi Korelasi Pearson Dalam Membangun Model TreeAugmented Network (TAN) (Studi Kasus Pengenalan Karakter Tulisan Tangan). Jurnal MATICS, No. 3, Vol. 5, Halaman 185-189.

[12] Irwan, B.S.(2013). Comparison of Pearson Correlation And Conditional Mutual Information To Construct Model of TreeAugmented Network (TAN)(Case study character handwriting recognition). The 4th International Conference Green Technology, Faculty of Science And Technology, Maulana Malik Ibrahim State Islamic University, Malang.

[13] Irwan, B.S.(2014). Deteksi Objek Nyata (Pada Lingkup: Visualisasi dan Deteksi Objek Nyata pada Lingkungan Hidup), Penelitian Penguatan Program Studi Fakultas Saintek UIN Malang.

[14] Irwan, B.S.(2014). Deteksi Boraks pada Bakso Berbasis Image dengan Menggunakan Tree-Augmeneted Bayesian Network (TAN). Penelitian Kompetitif Dosen LP2M UIN Malang.

[15] Kompas. (2010). Banjir dan Longsor Terjang Kota Malang. Surat Kabar Harian Kompas, 17 Februari 2010.

[16] Lab. PerencanaanLanskap Departemen Arsitektur Lanskap Fakultas Pertanian-IPB. Ruang Terbuka Hijau (RTH) Wilayah Perkotaan.

[17] Pablo B. et al. (2014). Speeding up incremental wrapper feature subset selection with Naïve Bayes classifier, KnowledgeBased Systems, Elsevier 55. 140-147

[18] Republika. (2008). Malang Sulit Kembangkan RTH [Online]. Dapat diakses di Republika.co.id, 12 Februari 2015.

[19] Republika. (2015). BRI Ancam RTH Kota Malang [Online]. Dapat diakses di Republika.co.id, 23 Februari 2015.

[20] Roswidyatmoko. (2013). Pemanfaatan Citra QuickBird untuk Identifikasi Ruang Terbuka Hijau Kawasan Perkotaan (Studi Kasus Kecamatan Serpong, Kota Tangerang Selatan). Seminar Nasional Pendayagunaan Informasi Geospatial untuk Optimaslisasi Otonomi Daerah 2013. 
[21] Tempo. (2008). Banjir Malang Akibat Pelanggaran Tata Ruang [Online]. Majalah online Tempo Interaktif, tersedia di www.tempointeraktif.com, 17 April 2008.

[22] Tempo. (2009). Banjir Bandang dan Tanah Longsor Terjang Malang, Satu Tewas [Online]. Majalah online Tempo Interaktif, tersedia di www.tempointeraktif.com, 24 Pebruari 2009.
[23] Tempo. (2010). Banjir Lumpuhkan Layanan PDAM Kota Malang [Online]. Majalah online Tempo Interaktif, tersedia di www.tempointeraktif.com, 5 Maret 2010.

[24] Tempo. (2013). Kota Malang Sudah Tak Nyaman Lagi [Online]. Dapat diakses di www.tempo.com, 23 Februari 2015. 